w Poznaniu

marekhendrykowski@gmail.com

\title{
Gorzkie kino. O Okupacji w 26 obrazach Lordana Zafranovicia
}

AbstRact: Hendrykowski Marek, Gorzkie kino. O Okupacji w 26 obrazach Lordana Zafranovicia (Bitter Cinema. On Occupation in 26 Pictures by Lordan Zafranović). "Poznańskie Studia Slawistyczne" 12. Poznań 2017. Publishing House of the Poznań Society for the Advancement of the Arts and Sciences, pp. 319-329. ISSN 2084-3011.

Analysis and interpretation of the film fresque made by Croatian director Lordan Zafranović (1978), a masterpiece of European art cinema of 70s. Marek Hendrykowski's study describes relationship between poetics of experience and aesthetics of shock. It also expresses the importance of mythical perspective (Babel Tower) and its meaning as the factor of common consciousness in keeping memory of the past in art and life of contemporary societies.

KEYwORDS: historical film; totalitarianism; genocide; poetics of experience; aesthetics of shock; oblivion; memory

\section{Dubrownickie pars pro toto}

W kulturze, skoro jest ona uprawą, nic nie jest dane na zawsze. Idea „długiego trwania” dotyczy nie tylko wydarzeń i procesów historycznych, lecz wszelkich dziedzin ludzkiej aktywności. Sięgam po dzieło filmowe sprzed lat, którego wymowa okazuje się dzisiaj niezwykle aktualna. Nie jestem pierwszym, którego uwagę przyciągnęła jego klasa artystyczna. Przede mną, również na łamach „Poznańskich Studiów Slawistycznych” o Okupacji w 26 obrazach w reżyserii Lordana Zafranovicia pisał niedawno Patrycjusz Pająk (2013: 185-201). Do jego wnikliwych rozważań i konstatacji będę się odwoływał w poniższym eseju - nie w trybie polemiki, lecz po to, by nawiązać z nimi dialog i spróbować rozwinąć pewne poruszone wątki w odmienny od zaproponowanego przez poprzednika sposób. 
Analizując poetykę twórczości tego reżysera, autor słusznie pisze:

Zafranović wypracowuje manieryczny i zmysłowy styl, który również można nazwać ornamentacyjnym $^{1}$. Służy on kreowaniu nastroju egzaltacji, będącej w twórczości chorwackiego reżysera kluczem do zrozumienia relacji między rytuałami kulturowymi a pierwotnymi ludzkimi potrzebami i odruchami (Pająk 2013: 187).

Trafne jest również, w moim przekonaniu, wskazanie na historycznofilmowy kontekst twórczości Zafranovicia, który wyznaczają filmy wielkich mistrzów włoskiego kina artystycznego: Federica Felliniego, Piera Paola Pasoliniego, Bernarda Bertolucciego i Luchina Viscontiego, w tym ostatnim przypadku zwłaszcza do widniejącego w tytule artykułu Patrycjusza Pająka fresku Zmierzch bogów.

Do listy tej dopisałbym jeszcze jedno intrygujące powinowactwo estetyki Okupacji w 26 obrazach, które stanowi pamiętna ekranizacja Romea i Julii Franka Zefirellego (1968). Skojarzenie z tym właśnie dziełem i analogia łącząca oba filmy dotyczy nie tylko wątku miłosnego i renesansowej urody ukazanego miasta, ale także śródziemnomorskiej $\mathrm{w}$ istocie wizji pewnego projektu kultury.

Dlaczego fenomen Jugosławii od dłuższego czasu nie przestaje fascynować Europy? Spośród wielu możliwych odpowiedzi na to intrygujące pytanie wybieram na użytek niniejszych rozważań jedną, jak się wydaje, newralgiczną. Jugosławia okazuje niejako Europą w pomniejszeniu, jej pars pro toto: krwawą areną kolejnego tragicznego w skutkach starcia między barbarzyństwem a cywilizacją, na której przykładzie - niczym w krzywym zwierciadle gorzkich i okrutnych dziejów - Europejczyk ogląda siebie.

Sarajewo, Vukovar, Srebrenica, Dubrownik... - celowo łamię i mieszam tutaj linearny porządek chronologiczny. Przez splot bałkańskich problemów, konfliktów, dramatów i tragedii przeziera wielusetletnia historia konfliktów narodów i państw dawnej Europy. Mowa o wiekach nienawiści, wyniszczających wojnach, wzajemnej wrogości i szalejącej wokół fanatycznej nietolerancji, która wielokrotnie ogarniała: Francję, Hiszpanię, Niemcy, Niderlandy, Czechy, Włochy i inne kraje europejskie, zabijając niezliczoną liczbę ludzi, siejąc mord, nienawiść i zniszczenie.

\footnotetext{
${ }^{1}$ Autor cytowanego artykułu nawiązuje tutaj do koncepcji ornamentalizmu w kinie modernistycznym zaproponowanej przez Andrása Bálinta Kovácsa w książce Screening Modernism. European Art. Cinema (Chicago 2007).
} 
W sztuce europejskiej (literaturze, rzeźbie, grafice, malarstwie, teatrze $\mathrm{i}$ in.) odnajdujemy niezliczone świadectwa istnienia tamtych ponurych wydarzeń odzwierciedlone w dziełach wielu artystów. Przypominają się w tym miejscu: Uccello, Dürer, Bruegel, Szekspir, Goya, Byron, Delacroix, Mickiewicz, Doré, De Amicis, Rodin, Sienkiewicz, Żeromski, Hašek, Brecht, Molnár, Dreyer, Picasso, Eisenstein, Strawiński, Tomasz Mann... Widowisko historyczne - pod warunkiem, że jego głównym celem nie jest pełna przepychu wystawa scenograficzna ani kostiumowy pietyzm, lecz coś więcej - może stać się nieocenionym instrumentem podtrzymywania i przywracania zbiorowej pamięci, zwłaszcza gdy okazuje się dziełem sztuki w pełnym tego słowa znaczeniu.

Film znajdujący się w centrum naszej uwagi nie był jednorazowym incydentem. Okupacja w 26 obrazach (1978) jest w twórczości chorwackiego reżysera Lordana Zafranovicia obrazem z intrygującą preakcją i jednocześnie dziełem z wymowną poakcją. Nie chodzi tylko o pewien epizod z dziejów kraju, lecz o prywatną historię i drogę artysty. Preakcję tworzy jego własna prywatna pamięć i dojrzewanie, zwłaszcza studia na praskiej FAMU pod kierunkiem Elmara Klosa (współreżysera słynnego Sklepu przy głównej ulicy, 1965). Ale także pierwsze filmy, które za młodu nakręcił w amatorskim klubie filmowym w Splicie. Już w początkach jego twórczości daje o sobie znać natychmiast wyczuwalny, dość nietypowy jak na tak młodego człowieka, zmysł historyczny: ze szczególnym podkreśleniem odwagi sięgania po wątki najtrudniejsze, bolesne, do dzisiaj nierozplątane i nieprzepracowane do końca.

\section{Splątana historia}

Zafranović należy do grona filmowców porażonych historią, zafascynowanych jej okrutnym, niepowstrzymanym, niszczącym wszystko na swojej drodze, bezrozumnym biegiem. O tym właśnie traktuje Okupacja w 26 obrazach. Paradoksalnie, historia wcale nie stoi w jego dziele na pierwszym planie. Wprawdzie w warstwie zewnętrznej reżyser rekonstruuje mroczny epizod dziejowy z czasów drugiej wojny światowej, jednak w strukturze głębokiej tego filmu daje o sobie znać o wiele ogólniejsza perspektywa, którą otwiera biblijny mit pomieszania języków ludzkości, znany jako mit wieży Babel. 
Dubrownik staje się tutaj opisaną w Księdze Rodzaju krainą Szinar. Należy podkreślić, że krwawy, okupacyjny dramat tego pięknego miasta nie jest bynajmniej traktowany przez artystę w kategoriach znaku sądu Bożego. Zostajemy skonfrontowani z jego własną wersją i interpretacją biblijnej opowieści. Ponieważ nie ma w tym filmie żadnej wznoszącej się ku niebu budowli, można odnieść wrażenie, że opowiadający wybrał drugie ze znaczeń słowa 'Babel' odnoszące się nie do wieży, lecz do miasta. Tak czy inaczej, Babel oznacza tutaj nie tyle ludzką uzurpację w postaci gigantycznej budowli mającej połączyć ziemię i niebo, ile przede wszystkim wywołane nią straszliwe zamieszanie i zamęt.

Część pierwsza, której akcja dzieje się w przededniu włosko-niemieckiej inwazji, ukazuje lokalny świat mieszkańców Dubrownika głęboko podzielony, naznaczony symptomami zbliżającej się zarazy faszyzmu, nazizmu i ustaszyzmu. Coś bardzo podobnego zbudował niemal w tym samym czasie Ingmar Bergman, portretując spustoszony klęską Niemiec krajobraz duchowy Republiki Weimarskiej w filmie Jajo węża (1977). Część druga Okupacji w 26 obrazach przynosi wstrząsającą wizję tragicznej w skutkach zagłady wspólnego dobra, jakim była lokalna Arkadia wraz z kultywowanym przez pokolenia mitem Croatia felix.

Niezwykle istotna w kontekście naszych rozważań wydaje się wypowiedź Lordana Zafranovicia, świadcząca o głębokiej samoświadomości artysty wobec własnego dzieła:

Pragnąłem (i spodziewam się, że mi się to udało) przedstawić okupację jako swoisty znak w szerszym znaczeniu. Kiedy mówię znak, mam na myśli to, co powodowało symptomatyczne przekształcenie losów ludzkich; sygnały znaczące wkroczenie do naszego miasta ubranego w czerń (uniformów) faszyzmu, z wszelkimi formami gwałtu, jakie mu towarzyszyły. (...) Miejsce okupacji, Dubrownik, wybrałem z wielu powodów. Przede wszystkim jest to miasto o wielkich tradycjach i określonej strukturze socjalnej; zafascynowała mnie możliwość ukazania przekształceń tej struktury podczas okupacji. Stąd też, z czysto filmowego punktu widzenia, wydawało mi się właściwe wykorzystanie jego piękna jako naturalnej przeciwwagi wszelkiego zła, przemocy i zbrodni okupacji. Cieszyłbym się, gdyby wszyscy odnaleźli w moim filmie to, co chciałem nim wyrazić: triumf dobra nad siłami zła, szlachetności nad podłością, miłości nad przemocą i zdradą (Horoszczak 1979).

Scenariusz, na podstawie wspomnień mieszkańca Dubrownika Mato Jakšicia, napisał Mirko Kovač, wybitny prozaik, reprezentant belgradzkiej elity literackiej (Danilo Kiš, Branislav Pekić, Branislav Šćepanović), autor 
powieści: Moja sestra Elida (1965), Rane Luke Meštrevicia (1971). To opowieść o czasach Zagłady, która w adriatyckim porcie kładzie okrutny kres nie tylko miejscowej społeczności Żydów, lecz również wszystkiemu, co tworzyło dotąd społeczną tkankę i duchową wielkość tego miasta.

W efekcie autorskich zabiegów wieloetniczny, wielojęzyczny i wielokulturowy Dubrownik przypomina w mniejszej skali to, czym jest wielonarodowa, wielojęzyczna i wielokulturowa Europa. Spoiwem jego i jej zbiorowych dokonań była harmonijna koegzystencja ludzkich wspólnot i odmiennych kultur. Film Zafranovicia nie idealizuje obrazu Dubrownickiej Republiki. Wprost przeciwnie, konsekwentnie i z realizmem pokazuje jak w organizmie miasta i społeczeństwa pojawia się i rośnie nowotwór narodowego socjalizmu, jak sieje w nim spustoszenie terror w potrójnej odmianie: faszystowskiej, hitlerowskiej i ustaszowskiej².

Okupacja w 26 obrazach unika mnożenia faktograficznych detali na rzecz ukazania ogólniejszego procesu. Autor nie zamierza odtwarzać ani tłumaczyć przebiegu tamtych wydarzeń na język zrozumiały w lokalnym kręgu, lecz przenosi rzecz na płaszczyznę metaforyczno-symboliczną, poszukując dla niej uniwersalnego „przekładu” na język mitu.

W będącym przestrogą wielkim micie ludzkości, którym są dzieje upadku wieży Babel, nie chodzi tylko o pomieszanie języków. Niezwykle intrygujący motyw filmu Zafranovicia stanowi co innego, mianowicie przenikliwa krytyka pośrednich i bezpośrednich skutków przemiany dokonywanej w imię totalitarnej (niszczącej wszystko co „obce” i „inne”) ideologii radykalnego postępu. Postępu wprowadzanego przemocą, oszalałego, osiąganego za wszelką cenę: łamiącego wszelkie bariery i granice.

Rzeczą niezmiernie intrygującą w Okupacji w 26 obrazach okazuje się intuicja artysty, który - wyróżniając słowo „obraz” w tytule swego filmu i tym samym nadając mu ważkie znaczenie - dociera do newralgicznego splotu relacji: zbiorowość-pamięć-obraz-historia. Nasuwa się w związku z tym pytanie: czyja to jest historia: narodu? narodów? miasta? Bałkanów?

\footnotetext{
${ }^{2}$ Wprowadzając to rozróżnienie, nie miałem na uwadze różnicy umundurowania, lecz trzy różne odmiany terroru: dwie zewnętrzne (inwazja włoska i niemiecka) oraz jedną ,,wewnętrzną" (rodzimą, ustaszowską). Skądinąd, owa podwójność dokonującej się inwazji nie jest w tym przypadku niczym wyjątkowym. Burzliwa historia Europy dostarcza wielu przykładów na to, że śmiertelne zagrożenie społecznego organizmu niekoniecznie pojawia się z zewnątrz, lecz bardzo często atakuje „od środka”.
} 
XX-wiecznej Europy? Do wywoływanej na nowo i opowiadanej przez siebie historii reżyser podchodzi niezwykle odważnie. W powiązaniu ze zbiorową pamięcią przypomina ona obraz, który wystąpił, wyrwał się z ram. Im bardziej obraz ten wychodzi z ram ekranu, tym bardziej wkracza w nas, domagając się empatii i osobistego zrozumienia.

To nie jest tylko wizyjna rekonstrukcja tragedii, która dotknęła prowincjonalny Dubrownik w roku 1941 wraz z ogłoszeniem Niezależnego Państwa Chorwackiego. Mamy tu o wiele więcej. Mało znany historyczny epizod z dziejów pięknego miasta autor filmu, wspólnie z jego współscenarzystą Mirko Kovačem, opowiada i przedstawia jako historię prywatną, dotyczącą życia nie mas, lecz jednostek. Niewyobrażalna masowa zbrodnia dokonana $\mathrm{w}$ tamtym czasie zostaje przez niego ukazana za pośrednictwem sekwencji dramatycznych zdarzeń, na powrót wtłoczonych w serię obrazów współtworzących ekranową opowieść o mieście i jego mieszkańcach. Autor nie zamienia jej w mit, lecz nadaje strukturę mityczną, by w sposób możliwie najbardziej nośny - opowiedzieć o tym, co się stało. Nowa pamięć z jej nośnym filmowym wyrazem staje tutaj do odważnej konfrontacji z zapomnieniem.

\section{W perspektywie poetyki doświadczenia}

Przyjaźń, miłość, piękno, szczytne ideały, wyrafinowana kultura, etos rycerski, honor, godność, duma, tradycja, karnawał, pogarda, skrywana nienawiść, podstęp, podłość, barbarzyństwo, zdrada, zbrodnia... Zestaw polimorficznych składników, które posłużyły do wykreowania ekranowej wizji Okupacji w 26 obrazach, wydaje się niezborny dopóty, dopóki nie odnajdzie się dla nich wspólnego mianownika w postaci poetyki zapisu doświadczenia. Mit dubrownickiej Arkadii i biblijna przypowieść o krainie Szinar łączą się w jedno, gdy uświadomić sobie zawarty w niej głębszy sens brutalnej lekcji historii.

Po jednej stronie mamy hołd złożony miłości do życia, harmonii egzystencji, zwykłemu bytowaniu, pracy, pięknu i trudom odwiecznej codzienności, muzyce i poezji. Po drugiej - potworny karnawał śmierci, w którym pandemonium niszczenia i zabijania stanowi istotę okrutnej zabawy w chwilowy triumf nadczłowieka. Pytanie, jak to wszystko pokazać na 
ekranie, aby spleść oba wątki w organiczną całość? Lordan Zafranović zdecydował się sięgnąć po rozbuchaną plastyczność łączącą w sobie groteskę i patos, wulgarność i wzniosłość - to, co „niskie” z tym, co „wysokie”.

Topos karnawału wykorzystał autor w niezwykle oryginalny i nader przewrotny sposób. Odwrócenie społecznych relacji, porządków i znaczeń nie służy tutaj ich odnowieniu, lecz zmierza do totalnego zanegowania dotychczasowego ładu świata, który przez wieki uczynił adriatyckie miasto tym, czym jest. Kres tego ładu - nadchodzący w wyniku okupacji kraju przez hordy swoich i obcych - niesie z sobą pogardę uzurpatorów dla wspólnej tradycji, prawa, wszelkiej odmienności, tolerancji, jedności w wielości, sztuki mądrego kompromisu i możliwości zgodnego współistnienia.

Złuda radykalnego postępu, który degraduje człowieka i zbiorowość, osiąga patologiczny wymiar rozkładu kultury i cywilizacji. Pomieszanie języków niesie z sobą upadek międzyludzkich relacji i norm społecznych. To, co szlachetne i przez wieki kultywowane jako wartość, ulega temu, co nieokrzesane, niskie i zbrodnicze. Kultura jako uprawa w nierównej walce z przemocą i barbarzyństwem ustępuje miejsca prostactwu i zdziczeniu umundurowanych.

Lordan Zafranović podejmuje w swoim filmie trud przepracowania zbiorowej pamięci historii, która się wydarzyła w jego własnym świecie trzy dekady wcześniej. Nie jest ważne, czy dawny Dubrownik był czy nie był wzorem europejskiej republiki miejskiej. Nie są również dzisiaj ważne koncesje ideologiczne A.D. 1978 (m.in. plakatowo wyidealizowany obraz komunistów). Ważne, co się wydarzyło wiosną 1941 roku i jak bardzo przez swoistą i ograniczoną postać tamtej tragedii przeziera wnikliwe spojrzenie na masową eksterminację i jej mroczne psychospołeczne źródła.

Cywilizacja w służbie totalitarnej ideologii odarta z kultury wyrosłej z ideałów humanizmu kieruje swą bezduszną aktywność przeciw człowiekowi, jego wielopokoleniowym dokonaniom i dziełom. Kult zbiorowej fanatycznej mocy i kult nowoczesności - odrzucający, potępiający i niszczący wszystko, co stare - umożliwia wznoszenie wyniosłych konstrukcji, sprawia jednak, że w ich monstrualnym ogromie i przeroście zagubiona zostaje właściwa miara ludzkiego życia i marzeń. Zburzymy stary świat, i na jego miejscu zbudujemy nowy, wspanialszy, potężniejszy. Niszcząca, destrukcyjna, ciemna energia fanatyków w zgubnym połączeniu ze 
słabą świadomością (czytaj bezmyślnością) wynikającą z prymitywnego postrzegania otaczającej rzeczywistości zapowiadają nadchodzący nieuchronnie zły scenariusz wydarzeń i ostateczną katastrofę. To, co lokalne, zyskuje wymiar o wiele głębszy i uniwersalny w swej wymowie.

Oderwanie uzurpatorskich aspiracji od ludzkiego wymiaru wysiłków i dzieł skutkuje tragedią. Biblijna opowieść o niebosiężnych dążeniach budowniczych, niepomnych konsekwencji własnego dzieła, stanowi nośną parabolę. Jej naznaczony goryczą metaforyczny sens wyrasta $z$ dramatycznego doświadczenia, które stało się udziałem zarówno człowieka, jak i zbiorowości. Biblijne pomieszanie języków jest skutkiem i karą za pychę ludzkości.

W świetle takiego ujęcia mit wieży Babel zawiera w swej strukturze głębokiej dwie odmienne wizje budowania. Po jednej stronie mamy zanegowaną i buńczucznie odrzuconą przez nierozumnych ludzi odwieczną ideę opartą na zdolnej do działania podmiotowej całości, która potrafi wspólnie samoorganizować się i tworzyć. Po drugiej - pojawiają się masy wznoszące bez głowy i na oślep gigantyczną podniebną budowlę na własną chwałe - uwieńczenie chorych od pychy marzeń i chwilowych iluzorycznych nadziei. Pierwsza $\mathrm{z}$ tych wizji czerpie $\mathrm{z}$ wielowiekowego doświadczenia, opierając sens swoich wysiłków na tradycji rozumnego i umiejętnego budowania. Druga - ostentacyjnie zrywa z przeszłością i w imię kultu nowego buduje coś, czego jeszcze nie było. Dwie przeciwstawne filozofie tworzenia i wyrosłe $\mathrm{z}$ nich dwa absolutnie różne ludzkie dzieła.

Zła krew wywołuje wśród części mieszkańców Dubrownika gorączkę nacjonalizmu. Niedawni przyjaciele stają się wrogami, nauczyciele prześladowcami, zwykli ludzie - nadludźmi. Dotyczy to nie tylko konfliktu dzielącego trzech głównych bohaterów: Chorwata Niko, Żyda Miho i Włocha Toniego, lecz także galerii postaci epizodycznych. Instruktor szermierczy o czeskim nazwisku Hubička ma się za rdzennego Chorwata, a jego nienawiść do Żydów czyni z niego antysemitę nie tyle rasowego, ile ideologicznego. Naznacza i poniża słabszego, bo sam czuje się kimś „gorszym”. Atawistyczne pragnienie przynależności do „swoich”, czyli „lepszych”, zniewala umysły owładnięte, by przywołać celne określenie Patrycjusza Pająka, „wulgarnością totalitarnego zepsucia”.

$\mathrm{Na}$ naszych oczach upada stare piękne miasto do niedawna będące schronieniem dla wielu i zdolne ich wszystkich pomieścić. Ginie 
zapomniane i porzucone dziedzictwo wzajemnego zrozumienia i tolerancji. Rozpad wznoszonej przez wieki budowli społecznej oznacza tu rozpad świata. A potem już tylko przeraźliwy skowyt żalu po utracie bezcennego dobra, które powinno było przetrwać i nadal istnieć. Demonstrując hekatombę Dubrownika, reżyser Okupacji w 26 obrazach nie szczędzi przy tym widzowi wstrząsających scen, które mają na celu wywołanie odrazy i fizjologicznej reakcji w postaci emocjonalnego szoku.

Nasuwa się pytanie: po co to pokazywać? Po co mnożyć obrazy kaźni i sceny okrucieństw? (skądś to znamy: „Myśmy wszystko zapomnieli, mego dziadka piłą rżnęli”). Należy pamiętać, że w tym przypadku poetyka filmu, używając drastycznych środków wyrazu, ma opisać przerażające doświadczenie ludzi poddanych opresjom totalitarnego reżimu, które nie może zostać zapomniane ani przemilczane. Chodzi o „historię spuszczoną z łańcucha" - doświadczenie tak potworne i ekstremalne, że niewytłumaczalne.

W dziele Zafranovicia $\mathrm{w}$ grę wchodzi jednocześnie wielka rana zbiorowej pamięci i milczenie tysięcy zamęczonych ofiar. Nie sposób o tym zapomnieć. Rysuje się tutaj funkcjonalna analogia między koszmarem sennym a koszmarem ekranowym. Koszmar senny pełni ważną rolę w życiu psychicznym człowieka. Pomaga przepracować traumę, oddala lęk, pozwala odzyskać dystans, uwalnia od strachu, oczyszcza psychikę. Gorzka katharsis, którą niesie wstrząsający film Zafranovicia, wynika z próby wniknięcia w przeszłość i wytłumaczenia wydarzeń do końca niewytłumaczalnych i niepojętych. W jego dziele poetyka doświadczenia łączy się w sposób głęboko przemyślany i artystycznie uzasadniony z estetyką szoku.

Autor epatuje widza okrucieństwem, a jego porażający obraz skumulowany został $\mathrm{w}$ siedmiominutowej sekwencji ukazującej egzekucję. Ale w centrum wykreowanej przez Zafranovicia generalnej wizji Dubrownika od pierwszej do ostatniej chwili istnieją: kultura, sztuka, tradycja, piękno, pamięć i prawda jako wartości słabe i wrażliwe, które okazują się niezniszczalne. Warto zauważyć, że obrazy ich unicestwiania także należą do poetyki doświadczenia. Od tamtego czasu nakręcono wiele filmów zawierających nieporównanie bardziej okrutne i wstrząsające obrazy totalitarnego zdziczenia. Rzecz w tym, aby ukazując przemoc i zbrodnię, nie zagubić po drodze sensu jej zademonstrowania na ekranie. 
Okupacja w 26 obrazach jest dzisiaj filmem historycznym, jednak jej emocjonalne źródła i osobiste dramaty nadal dają o sobie znać w sztuce Bałkanów. Mowa tu nie o ujęciu ze szkolnego podręcznika, lecz o ,żywej historii" - obojętne w tym momencie - faktograficznej czy fikcyjnej. Wysuwane pod adresem filmu krzywdzące i niesprawiedliwe zarzuty o zmyślenie stały się dla autora kwestią tak ważną, że wkrótce nakręcił swoisty aneks do swego filmu: krótkometrażowy dokument dotyczący stricte tematu kaźni w autobusie Slobodna interpretacija (1979).

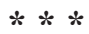

Film historyczny i powieść historyczna sięgają do przeszłości, czerpią z niej i ją opisują, ale nie mogą jej przeinaczać. Poetyka doświadczenia jest tak czy inaczej poetyką faktów. Fikcja artystyczna, z racji swego zasięgu i siły kreacyjnego oddziaływania, ma w tym względzie do wypełnienia szczególną misję. Misję wciąż aktualną i nigdy nieprzedawnioną. Zapewne nie jest dziełem przypadku, że ekranowa opowieść chorwackiego reżysera doczekała się niedawno swoistej kontynuacji w powieści laureata nagrody literackiej Angelus za rok 2012, Miljenka Jergovicia zatytułowanej Wilimowski (2016). Zbieżność obu artystycznych wizji okazuje się momentami uderzająca. Ich analiza porównawcza to jednak temat na inną, oddzielną okazję.

Dzieło Lordana Zafranovicia unika faktograficznej dosłowności i ze względu na swoją poetykę - umiejętnie operującą paraboliczno-mityczną konstrukcją - nadal pozostaje otwarte i podatne na rozmaite interpretacje. Przedstawiona tutaj alternatywna wobec poprzedników propozycja jego odczytania wskazuje na interesujący trop interpretacyjny, którym jest mit wieży i miasta Babel oraz biblijnej krainy Szinar.

Ogólniejsza konkluzja, która wynika z powyższych rozważań, przedstawia się następująco. Po pierwsze, gorzki film Zafranovicia uświadamia, że dramatyczne dzieje Bałkanów stanowią integralną część wielowiekowych doświadczeń historycznych Europy. Nie chodzi w nim bynajmniej o protokolarną dokumentację i rekonstrukcję ówczesnych wydarzeń (mówimy przecież o filmie fikcji!), lecz o szerszą historiozoficzną refleksję nad powtarzającym się mechanizmem nowożytnego barbarzyństwa. Po drugie, konsekwentnie przywoływany i eksponowany w Okupacji w 26 obrazach mit kultury śródziemnomorskiej zawiera $\mathrm{w}$ sobie koncepcję człowieka 
i życia jako wartości uniwersalnej. Wartość owa jest tylko projektem, wyobrażeniem i niespełnioną do końca ideą, co wcale nie znaczy, że w obliczu krwawej historii i w zderzeniu ze współczesnością mielibyśmy jej odbierać moc sprawczą, jakkolwiek ograniczona by ona nie była. I po trzecie, dyskretnie przywołany przez autora mit dotyczący wieży Babel i tego, co się wydarzyło w krainie Szinar - jako symboliczny zapis pewnego doświadczenia ludzkości - pozwala rozpoznać i niezwykle sugestywnie opisać szerszą dziejową prawidłowość, tę mianowicie, że wszelki kryzys społeczno-polityczny zaczyna się zawsze tak samo: od pomieszania języków.

Pomieszanie owo, ilekroć daje o sobie znać, stanowi groźny symptom zapowiadający nadchodzącą katastrofę. Pojawia się ono na długo przedtem, zanim nastąpi akt agresji, aneksja i zawłaszczenie wspólnego terytorium przez którąś ze stron. Nie chodzi o terytorium w pojęciu geopolityki, lecz o sferę symboliczną, ergo język jako instrument porozumienia. Gdy ustaje dialog, zanika pospólna wola kompromisu i akceptacja dla różnorodności wielobarwnej wspólnoty, a rzeczywistość zabudowują urojone fantazmaty wodzów i pełne czczych obietnic miraże ich poddanych. Zamieszkiwana przestrzeń - dotąd będąca przedmiotem ciągłego kompromisu i nieustannych negocjacji - staje się przestrzenią nieodwracalnego, tragicznego w skutkach konfliktu. W tym sensie dzieje budowy wieży Babel pozostają nigdy nieukończoną historią, którą należy przypominać stale od nowa.

\section{Literatura}

Assorodobraj N., 1963, Żywa historia. Świadomość historyczna. Symptomy i propozycje badawcze, „Studia Socjologiczne” nr 2, s. 204-205.

Halbwachs M., 1969, Społeczne ramy pamięci, przeł. M. Król, Warszawa.

Horoszczak A. (oprac.), 1979, Lordan Zafranović: wypowiedź opublikowana w materiałach XXV Festiwalu Filmów Jugostowiańskich w Puli, „Filmowy Serwis Prasowy" nr 12, s. 17-18.

Jergović M., 2016, Wilimowski, przeł. M. Petryńska, Warszawa.

Oakeshott M., 1999, Wieża Babel i inne eseje, przeł. A. Lipszyc, Ł. Sommer, M. Szczubiałka, Warszawa.

Traba R., 2006, Historia - przestrzeń dialogu, Warszawa.

Kovács A.B., 2007, Screening Modernism. European Art Cinema 1950-1980, Chicago. Ricoeur P., 2012, Pamięć, historia, zapomnienie, przeł. J. Margański, Warszawa. Nycz R., 2012, Poetyka doświadczenia. Teoria - nowoczesność - literatura, Warszawa. Pająk P., 2013, Zmierzch bogów, „Poznańskie Studia Slawistyczne” nr 5, s. 185-201. 